\title{
3D Physical Simulation Experiment of Edge Water Reservoir by Polymer/Surfactant Binary Flooding
}

\author{
Qunyi Wang, Wenshuang Geng ${ }^{(D)}$, Fuquan Luo, Changcheng Gai, Xuena Zhang, \\ and Xiao Gu \\ Research Institute of Exploration and Development, Jidong Oilfield Company, PetroChina, Tangshan 063004, China \\ Correspondence should be addressed to Wenshuang Geng; gengwenshuang@126.com
}

Received 16 March 2020; Revised 23 April 2020; Accepted 27 April 2020; Published 13 May 2020

Guest Editor: Dongying Wang

Copyright $\odot 2020$ Qunyi Wang et al. This is an open access article distributed under the Creative Commons Attribution License, which permits unrestricted use, distribution, and reproduction in any medium, provided the original work is properly cited.

\begin{abstract}
To investigate the enhanced oil recovery (EOR) technology by chemical flooding in an edge water reservoir, a 3D physical simulation experimental device for the edge water reservoir was developed, and polymer/surfactant binary flooding experiments were carried out under different edge water energies. In addition, the effect and mechanism of binary flooding on EOR under different edge water energies were comprehensively analyzed. Experimental results show that edge water intrusion considerably affects EOR by binary flooding. The stronger the edge water energy, the worse the effect of EOR by binary flooding. Edge water possibly diluted the concentration of the chemical agent medium that is injected into the reservoir, and the degree of dilution varied in different regions. The dilution region was mainly distributed between the injection wells and edge water. The stronger the edge water energy, the higher the dilution multiple of chemical agent and the greater the recovery loss rate by binary flooding.
\end{abstract}

\section{Introduction}

Edge water reservoir is widely distributed all over the world. The oil production of active edge water reservoir is one of the most challenging problems in petroleum development. In most of these reservoirs, it is likely to form a large water channeling. This phenomenon, which occurs quickly, leads to a rapid increase in the water content of the reservoir. The inflow of water then limits oil recovery, leading to a significant decline in well production [1-3]. However, if the edge water can be effectively restrained or utilized in time, it can once again become a positive energy to improve the development efficiency [4].

For many years, the influence of polymer blocks on bottom water reservoir development has been systematically studied [5]. In addition, some scholars have studied the injection of chemical agents to block the dominant channels and transfer the oil displacement agent to the uncleaned areas. These reported chemical agents include emulsions, foams, air, nanoparticles, and gels [6-9].

The shallow reservoir of the Jidong Oilfield is a typical medium-high permeability natural water drive reservoir, with an average porosity of $29 \%$ and an average permeability of $494 \mathrm{mD}$ [10-12]. The depth of the reservoir is shallow, between 1500 and $2400 \mathrm{~m}$, the fault block area is small, and the average oil-bearing area is only $0.20 \mathrm{~km}^{2}$. There are faults in the reservoir, and some areas are connected with the external natural waters, with a certain amount of edge water energy. Currently, this reservoir is at the ultrahigh watercut stage. The composite water cut is greater than $90 \%$, and the degree of reserve recovery is less than $20 \%$. Hence, enhanced oil recovery (EOR) technologies for this type of a reservoir needs to be investigated [13-16]. As a mature and effective oil recovery technology, chemical flooding has garnered increasing attention [17-19]; however, the invasion of edge water has always been an important factor that reduces the effect of chemical flooding. Hence, it is imperative to explore the oil displacement mechanism of chemical flooding in the edge water reservoir [20-23].

In this study, a three-dimensional (3D) physical simulation experimental device for the edge water reservoir is developed according to an actual reservoir. In addition, by employing 3D physical simulation experiments of the polymer/surfactant binary flooding under three water 
energy conditions, i.e., no edge water, weak edge water, and strong edge water, respectively, the EOR mechanism by binary flooding under different edge water energy conditions is comprehensively analyzed.

\section{Model Research and Experimental Design}

2.1. Model Research. According to the characteristics of the shallow reservoir of the Jidong Oilfield such as a small oilbearing area and active edge-bottom water, a set of $3 \mathrm{D}$ physical simulation experimental devices for the edge water reservoir is developed on the basis of the actual reservoir parameters. The experimental process is shown in Figure 1. The device consists of a model system, a data acquisition and processing system, an automatic control system, a production metering system, and an auxiliary system. Some water intrusion channels are set outside the 3D model, while the edge water permeation plate is set inside the 3D model, which was composed of filling holes and filter mesh. The edge water is injected by an ISCO pump via the outside water invasion channels, infill holes, and filter mesh. And all of these can support the experimental research on the law of water flooding and chemical flooding under the multidirectional edge water invasion condition.

The main parameters are as follows.

The maximum experimental temperature and maximum experimental pressure are $200^{\circ} \mathrm{C}$ and $10 \mathrm{MPa}$, respectively; the internal size of the pressure chamber is $300 \times 300 \times 200 \mathrm{~mm}$; the number of pressure measuring points is 40 ; the number of differential pressure measuring points is 30 ; and the number of resistivity measuring points is 64 .

The well network in line drive mode is designed on the basis of the shallow reservoir in the Jidong Oilfield (Figure 2). At the water flooding stage, B1-B5 are production wells, which are driven by edge water energy. At the polymer/surfactant binary flooding stage, B1 and B2 are injection wells and B3-B5 are production wells. To dynamically identify the reservoir fluid distribution during the 3D physical simulation, 36 sets of resistivity probes are set up in the model to monitor the changes of resistivity at different locations as well as development phases (Figure 3). Eighteen sampling ports at different locations are set up to sample formation fluids and analyze the chemical agent concentration.

2.2. Experimental Materials. Experimental water is the formation water from the shallow reservoir in the Jidong Oilfield; the type of water is $\mathrm{NaHCO}_{3}$; and the total salinity is $1635 \mathrm{mg} / \mathrm{L}$. The experimental oil is the simulated oil from the shallow reservoir in the Jidong Oilfield, the crude oil viscosity is $5.0 \mathrm{mPa} \cdot \mathrm{s}$ at $70^{\circ} \mathrm{C}$, the surfactant (betaine) solution concentration is $0.5 \%$, the polymer hydrolyzed polyacrylamide (HPAM) concentration is $1500 \mathrm{mg} / \mathrm{L}$, and the molecular weight is $1200 \times 10^{4}-1600 \times 10^{4}$.

2.3. Experimental Scheme. Based on the similarity criterion, the experimental parameters are calculated according to the PV number. For flow rate and permeability, according to
Darcy's law, if other parameters remain unchanged, the flow rate and permeability are reduced by 100 times in equal proportion. On the basis of the reduced flow rate, the prototype and the model are compared to ensure that the PV number of the injected fluid is the same to determine the injection time of the model. The experimental parameters are determined (Table 1), and the experimental scheme is designed as follows:

(1) The injection rate of edge water flooding is $2.5 \mathrm{~mL} /$ $\min$

(2) When the water cut is up to $98 \%$, the polymer/ surfactant binary flooding under different edge water energy conditions should be carried out, as shown in Table 2

(3) When the polymer/surfactant binary flooding is completed, water flooding is carried out at a rate of $2.5 \mathrm{~mL} / \mathrm{min}$ until the composite water cut reaches $98 \%$.

It is worth mentioning that, through the numerical simulation part, the intrusion speed of the weak edge water and strong edge water (80 and 500 times, respectively) was determined. By adjusting the relationship between the water body multiple and the bottom-hole flowing pressure drop of the edge water drive, the weak and strong water injection rates were determined. Eventually, the experimental schemes of boundless water chemical flooding, weak edge water chemical flooding, and strong edge water chemical flooding were formed.

\section{Experimental Results and Analysis}

3.1. Effect of Edge Water on Polymer/Surfactant Binary Flooding. To examine the effect of edge water on the production effect of polymer/surfactant binary flooding, the oil production under different edge water energy conditions is compared. The data obtained from each experimental stage are summarized in Table 3. Based on the experimental data, the curves of the recovery degree and average water cut curves are shown in Figures 4 and 5, respectively.

It can be drawn from Figures 4 and 5 that the production time of the polymer/surfactant binary flooding with weak edge water is the longest, that without edge water is the second, and that with strong edge water is the shortest. The decrease in the average water cut for the polymer/surfactant binary flooding without edge water is the highest, up to $23.90 \%$, while the corresponding values for the polymer/ surfactant binary flooding with weak edge water and strong edge water were similar, i.e., $10.74 \%$ and $12.95 \%$, respectively. The degree of recovery for the polymer/surfactant binary flooding without edge water is $9.12 \%$, while the corresponding values for the polymer/surfactant binary flooding with weak edge water and strong edge water are $6.67 \%$ and $3.76 \%$, respectively. The development effect of the polymer/surfactant binary flooding without edge water is better than that of the weak edge water, and the effect of binary flooding with weak edge water is better than that with strong edge water. 


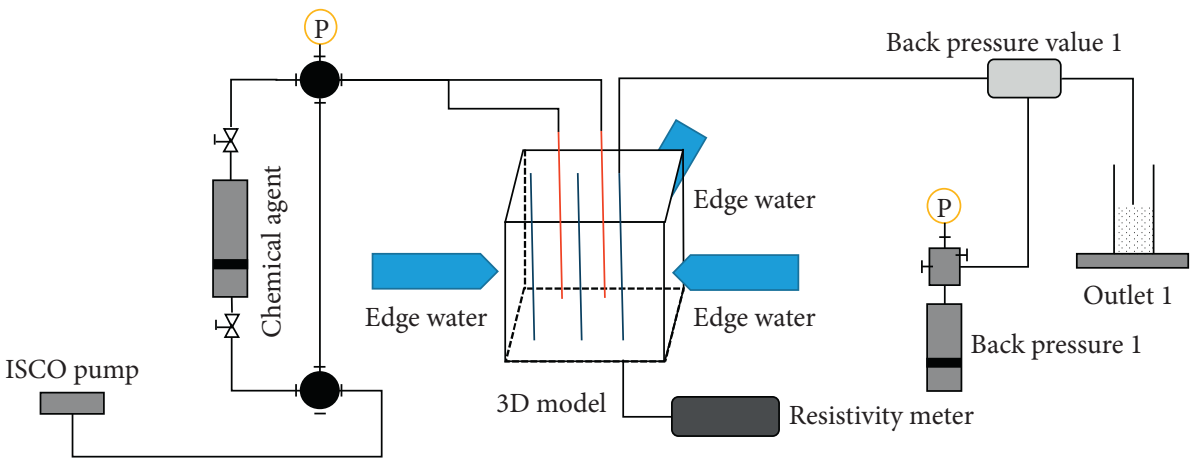

FIGURE 1: Experimental procedure of a high-temperature, high-pressure 3D reservoir simulation system.

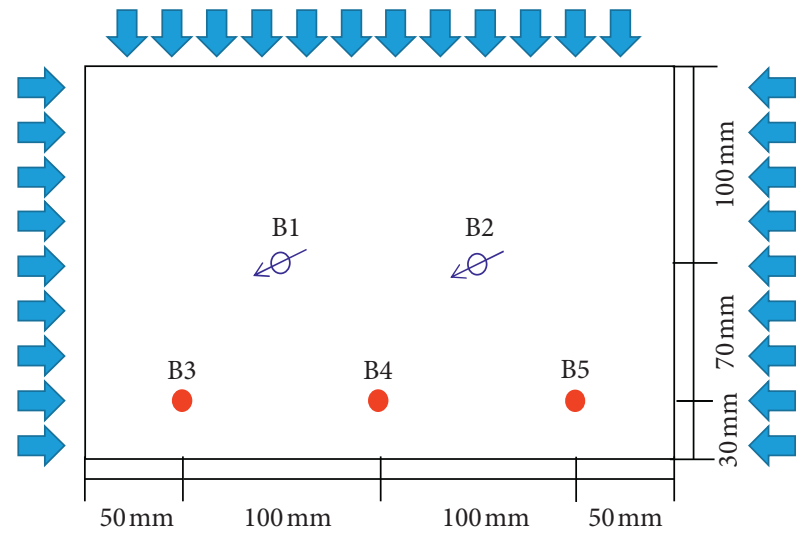

(a)

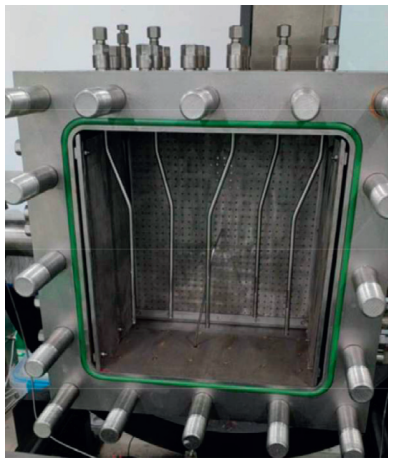

(b)

Figure 2: Well location of the 3D physical simulation experiment.
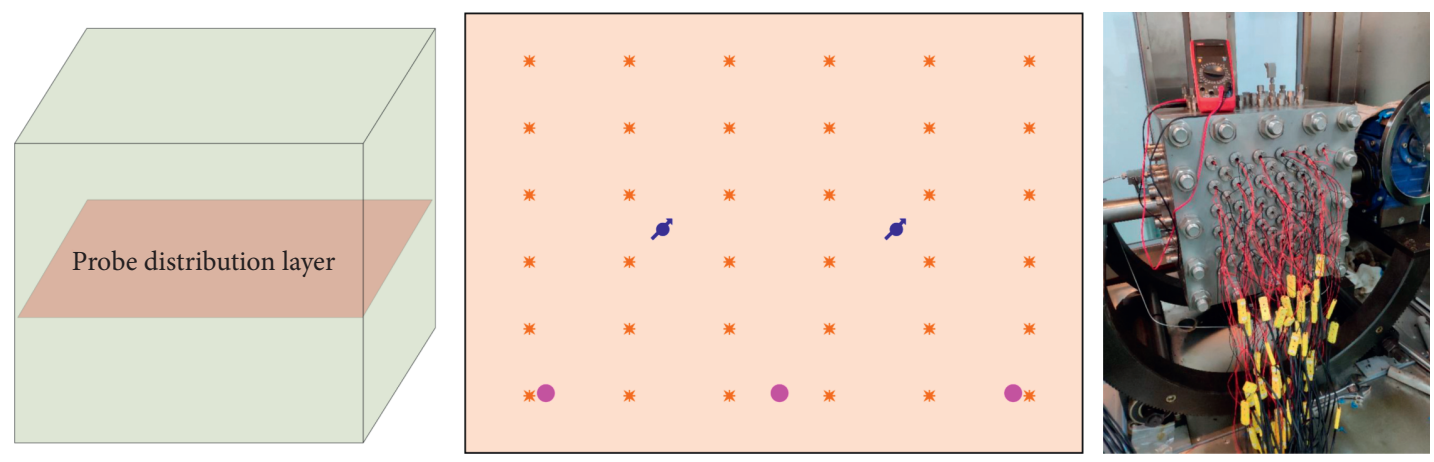

FIgURE 3: Electrode distribution of the 3D physical simulation experiment.

TABLE 1: Experimental parameters.

\begin{tabular}{lcc}
\hline Items & Reservoir parameters & Experimental parameters \\
\hline Inclination angle & $5^{\circ}$ & $5^{\circ}$ \\
Effective thickness & $5 \mathrm{~m}$ & $30 \mathrm{~cm}$ \\
Temperature & $70^{\circ} \mathrm{C}$ & $70^{\circ} \mathrm{C}$ \\
Horizontal permeability & $877 \mathrm{mD}$ & $3300 \mathrm{mD}$ \\
Porosity & $29 \%$ & $40 \%$ \\
Injection rate & $80 \mathrm{~m}^{3} / \mathrm{d}$ & $1.5 \mathrm{~mL} / \mathrm{min}$ \\
\hline
\end{tabular}


TABLe 2: Parameters of the displacement experiment scheme.

\begin{tabular}{|c|c|c|c|c|}
\hline Number & Experimental scheme & $\begin{array}{l}\text { Injection rate of edge } \\
\text { water }\end{array}$ & $\begin{array}{c}\text { Injection rate of chemical } \\
\text { agent }\end{array}$ & $\begin{array}{l}\text { Liquid production } \\
\text { rate }\end{array}$ \\
\hline 1 & $\begin{array}{l}\text { Polymer/surfactant binary flooding without edge } \\
\text { water }\end{array}$ & 0 & $1.50 \mathrm{~mL} / \mathrm{min}$ & $1.50 \mathrm{~mL} / \mathrm{min}$ \\
\hline 2 & $\begin{array}{c}\text { Polymer/surfactant binary flooding with weak } \\
\text { edge water }\end{array}$ & $0.13 \mathrm{~mL} / \mathrm{min}$ & $0.47 \mathrm{~mL} / \mathrm{min}$ & $0.60 \mathrm{~mL} / \mathrm{min}$ \\
\hline 3 & $\begin{array}{c}\text { Polymer/surfactant binary flooding with strong } \\
\text { edge water }\end{array}$ & $1.00 \mathrm{~mL} / \mathrm{min}$ & $1.50 \mathrm{~mL} / \mathrm{min}$ & $2.50 \mathrm{~mL} / \mathrm{min}$ \\
\hline
\end{tabular}

Table 3: Production data of each experimental stage.

\begin{tabular}{lccc}
\hline Parameter design & $\begin{array}{c}\text { Polymer/surfactant binary flooding } \\
\text { without edge water }\end{array}$ & $\begin{array}{c}\text { Polymer/surfactant binary flooding } \\
\text { with weak edge water }\end{array}$ & $\begin{array}{c}\text { Polymer/surfactant binary flooding } \\
\text { with strong edge water }\end{array}$ \\
\hline $\begin{array}{l}\text { Injected PV } \\
\text { flooding without edge water) + 0.39 } \\
\text { (following water flooding) }\end{array}$ & $\begin{array}{c}0.34 \text { (polymer/surfactant binary } \\
\text { flooding with weak edge water) }+1.15 \\
\text { (following water flooding) }\end{array}$ & $\begin{array}{c}0.29 \text { (polymer/surfactant binary } \\
\text { flooding with strong edge } \\
\text { water) + 0.51 (following water } \\
\text { flooding) }\end{array}$ \\
$\begin{array}{l}\text { Cumulative } \\
\text { production }(\mathrm{mL})\end{array}$ & 677 & 500 & 282 \\
Recovery degree $(\%)$ & 9.12 & 6.67 & 3.76 \\
\hline
\end{tabular}

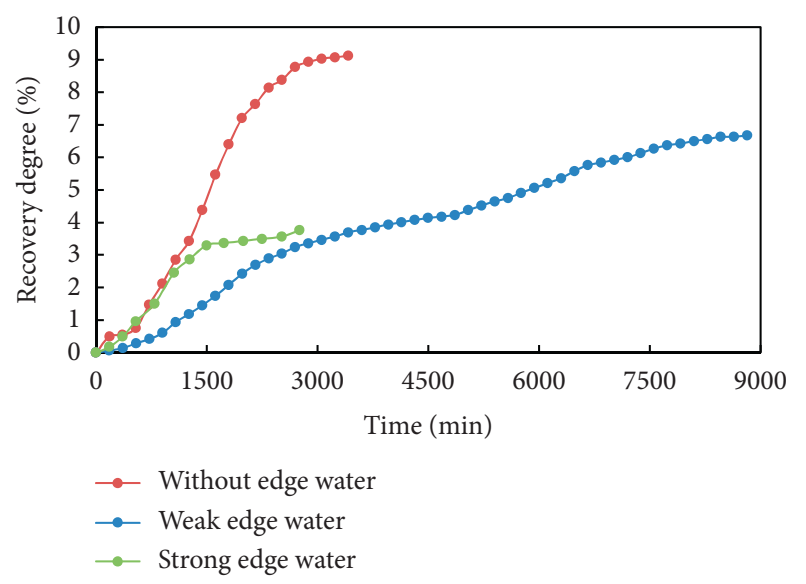

FIGURE 4: Curves of the recovery degree under different edge water energy conditions.

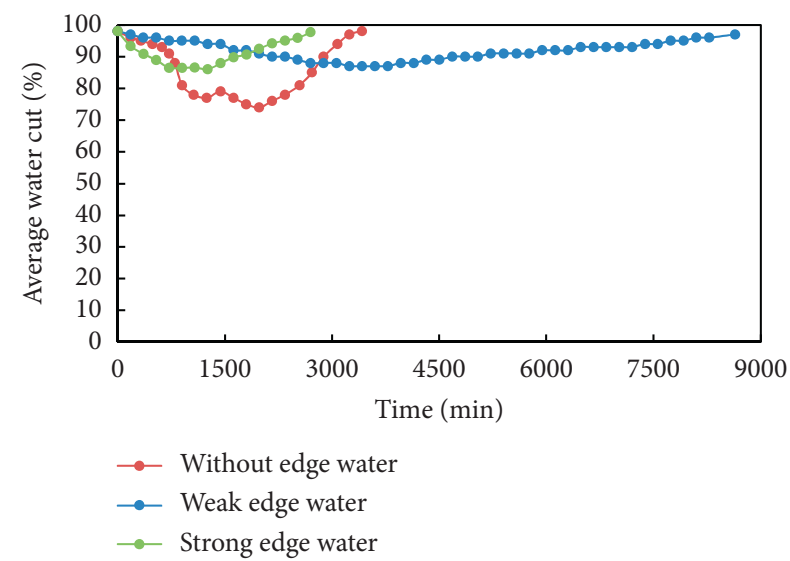

FIgURE 5: Curves of the average water cut under different edge water energy conditions.
3.2. Effect of Edge Water on the Remaining Oil Saturation during Polymer/Surfactant Binary Flooding. Figures 6 and 7 show the remaining oil saturation distributions for the polymer/surfactant binary flooding with strong edge water and without edge water, respectively. To more intuitively compare the effects of binary flooding under different edge water energy conditions, the remaining oil saturation of binary flooding with strong edge water is subtracted from that of binary flooding without edge water. Figure 8(a) shows the distribution of the remaining oil saturation of binary flooding under edge water. The difference of the remaining oil saturation between strong edge water and no edge water is divided into positive and negative regions. The negative region is where the edge water action is beneficial to the remaining oil production, and the positive area is the unfavorable one (Figures 8(b) and 8(c)), respectively.

From Figure 8, the best area to exploit the remaining oil is confirmed to be between the edge water region and injection wells, while the effect of the edge water is clearly not conducive to produce the remaining oil in the area between injection and production wells. Hence, the presence of edge water is not beneficial to the overall production of the remaining oil, especially the remaining oil between the injection and production wells.

3.3. Effect of Edge Water on Polymer Concentration. With the increase in the polymer concentration, the solution viscosity increases. As a crucial factor in the polymer/surfactant binary flooding, the polymer viscosity can improve oil recovery via the control of the oil-water mobility. The change in concentration of the precursor polymer is the indirect reference to reflect the change in the polymer viscosity. By sampling and analysis, the variation diagrams of the polymer concentration fields with different injection volumes $(0.3 \mathrm{PV}$ and $0.6 \mathrm{PV}$; the following waterflooding is carried out until 


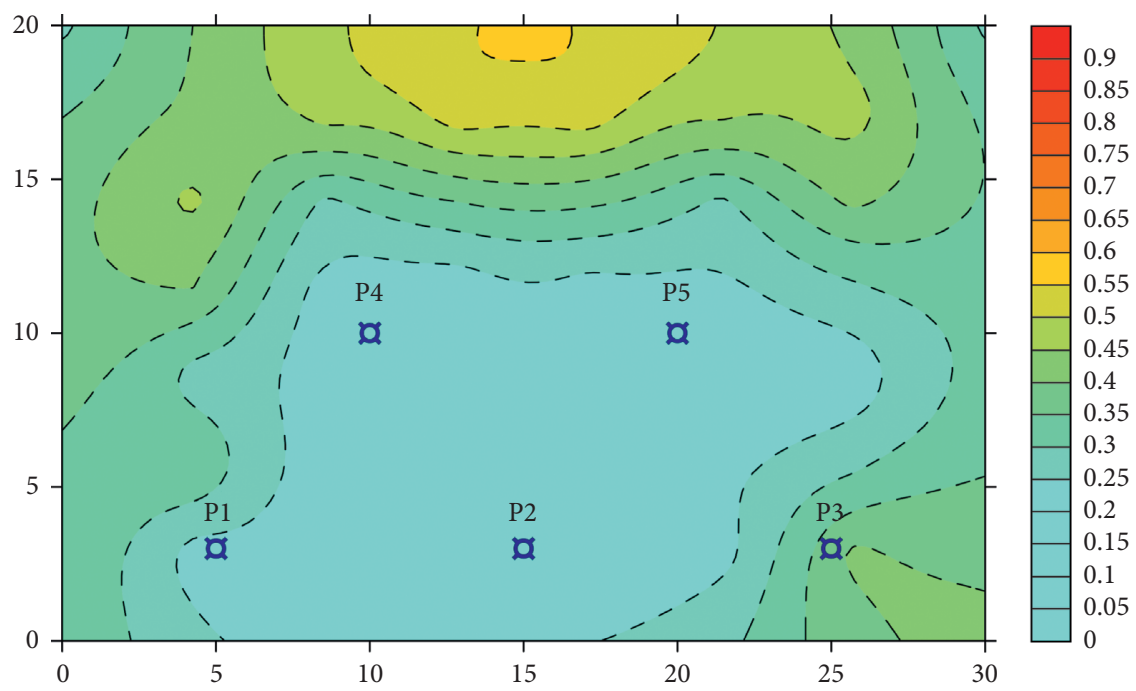

FIGURE 6: Remaining oil saturation distribution of binary flooding with no edge water.

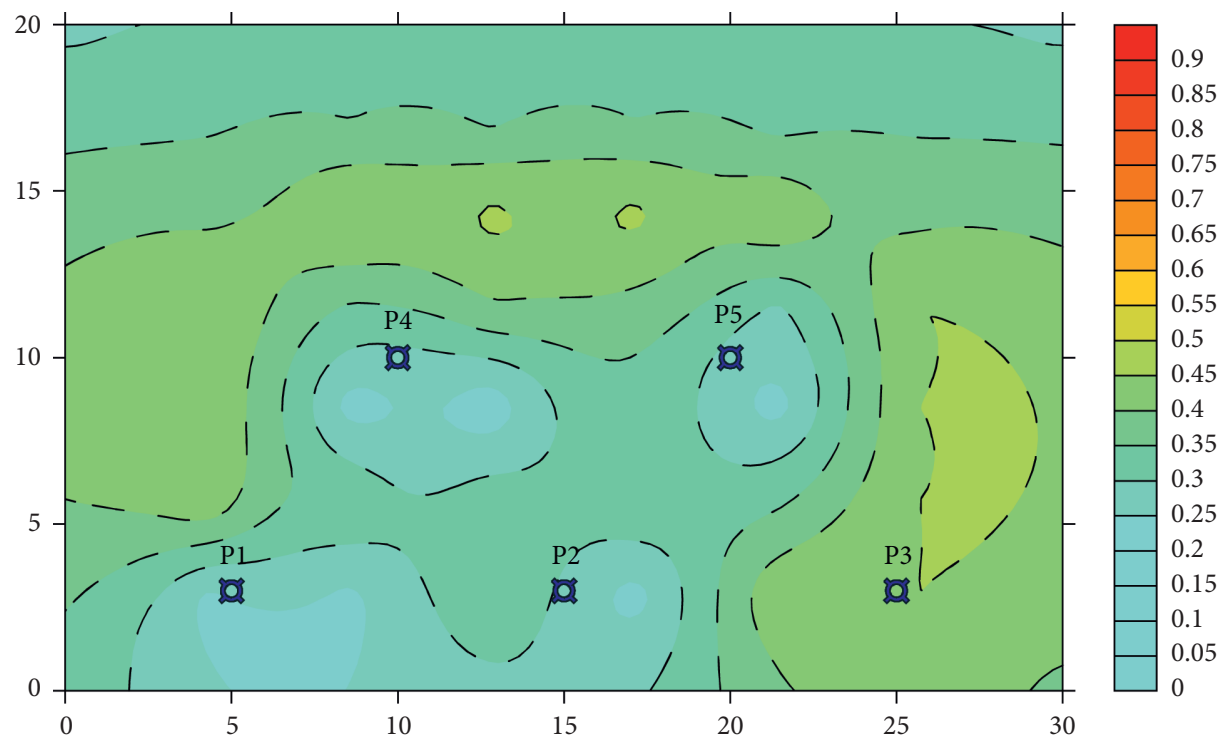

FIGURE 7: Remaining oil saturation distribution of binary flooding with strong edge water.

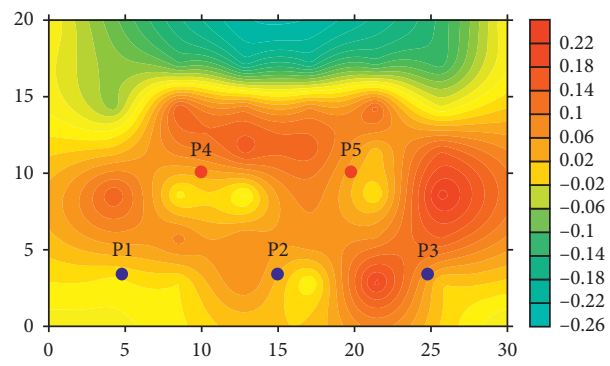

(a)

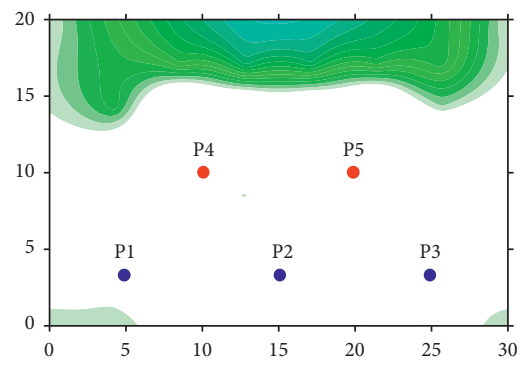

(b)

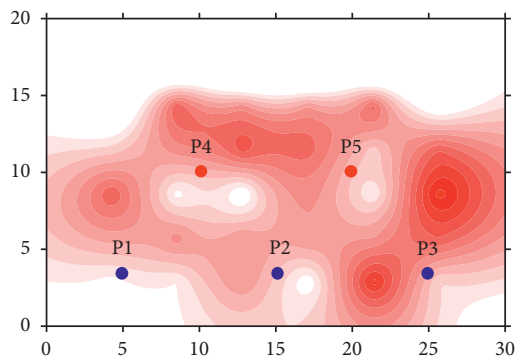

(c)

FIGURE 8: Difference diagram of the remaining oil saturation during binary flooding under different water energy conditions. (a) Whole region. (b) Negative region. (c) Positive region.

the water cut is 98\%) in the chemical agent injection process with no edge water, weak, and strong edge water are obtained (Figures 9-11, respectively).
With the increase in the polymer injection volume, the polymer distribution region exhibits a "heart-shaped" expansion potential, and the concentration gradually increases 


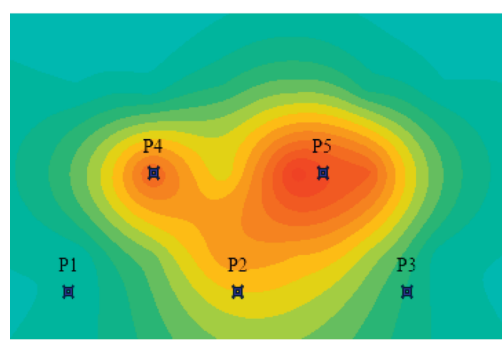

$0.3 \mathrm{PV}$

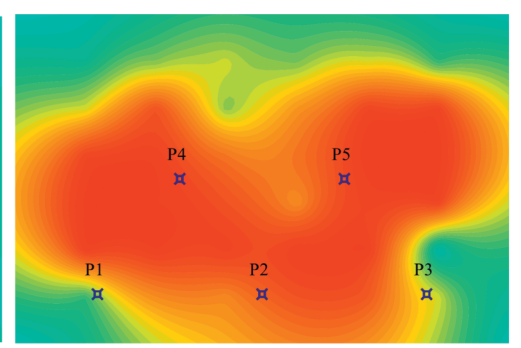

$0.6 \mathrm{PV}$

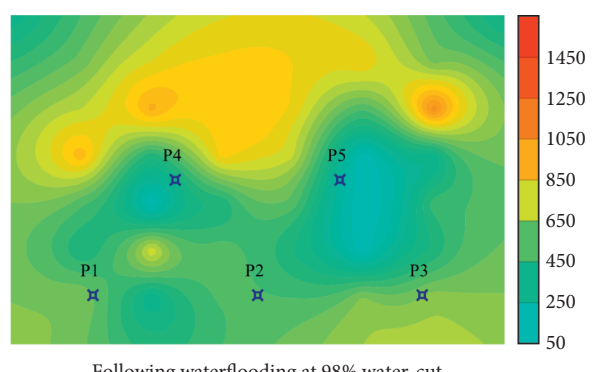

Following waterflooding at $98 \%$ water-cut

FIGURE 9: Variation of the polymer concentration field during chemical injection with no edge water.

under the no edge water condition (Figure 9). With the injection of $0.6 \mathrm{PV}$, the polymer is mainly distributed in the areas near injection well 1 and injection well 2 and between injection and production wells; the following water flooding process drives the polymer outside the "heart shape," i.e., outside the injection-production wells; and the polymer concentration decreases accordingly.

When the same volume of the chemical agent is injected, the distribution area and concentration of the polymer under the three conditions of no edge water, weak edge water, and strong edge water, respectively, decrease in turn (Figures 10 and 11). Under the edge water condition, with the injection of $0.6 \mathrm{PV}$, the polymer mainly distributes between injection well 1 , injection well 2 , and production well 2. The range of the polymer distribution under the strong edge water condition is less than that under the weak edge water condition, that is, the "heart" area is smaller and the concentration is lower.

3.4. Dilution Multiple. To compare the concentration difference of the polymer flooding front under different edge water energy conditions, the dilution multiple concept is defined, which is the ratio of the chemical concentration with no edge water and with edge water; the dilution multiple characterizes the dilution degree of the edge water to the chemical agent.

The dilution multiple of the polymer concentration under strong and weak edge water conditions is converted into field diagrams (Figures 12 and 13). At the chemical injection stage, the invasion of edge water dilutes the polymer concentration. The stronger the edge water energy, the higher the dilution multiple. The area percentage of the strong edge water dilution to the chemical agent is $83 \%$ and that of the weak edge water dilution to the chemical agent is $48 \%$.

The dilution degree is different in different areas, and the dilution area is mainly distributed in the area between the injection well and edge water (Figures 12 and 13). The dilution multiples of different regions are quantitatively evaluated by taking the average value (Figure 14). The dilution multiple between the injection well and edge water in a strong edge water reservoir is 2.2 , while that between injection wells and production wells is only 1.3. In the weak edge water reservoir, the dilution multiple between the injection well and edge water is 1.6, and the dilution multiple between injection wells and production wells is 1.1. The

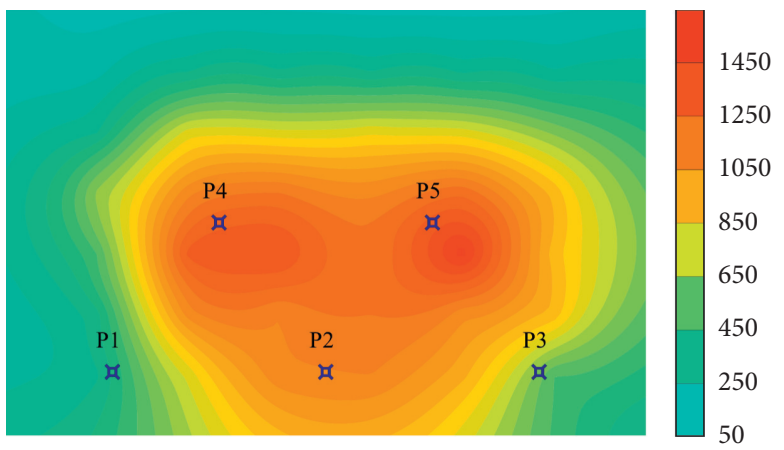

FIGURE 10: Polymer concentration field during binary flooding with weak edge water (0.6 PV).

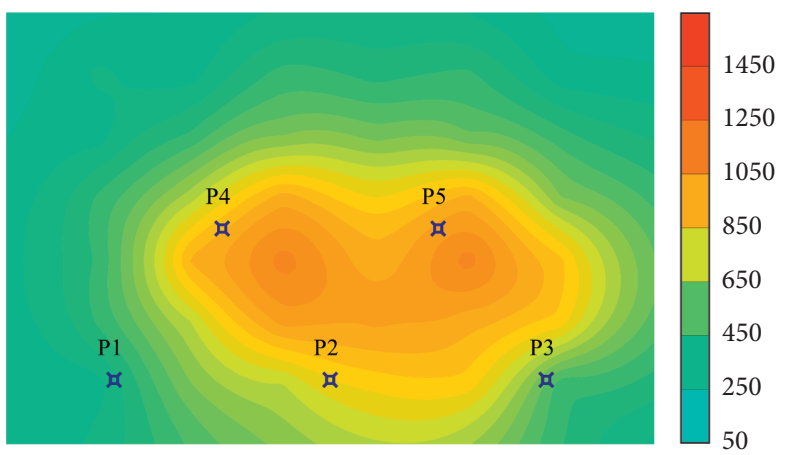

FIgURe 11: Polymer concentration field during binary flooding with strong edge water $(0.6 \mathrm{PV})$.

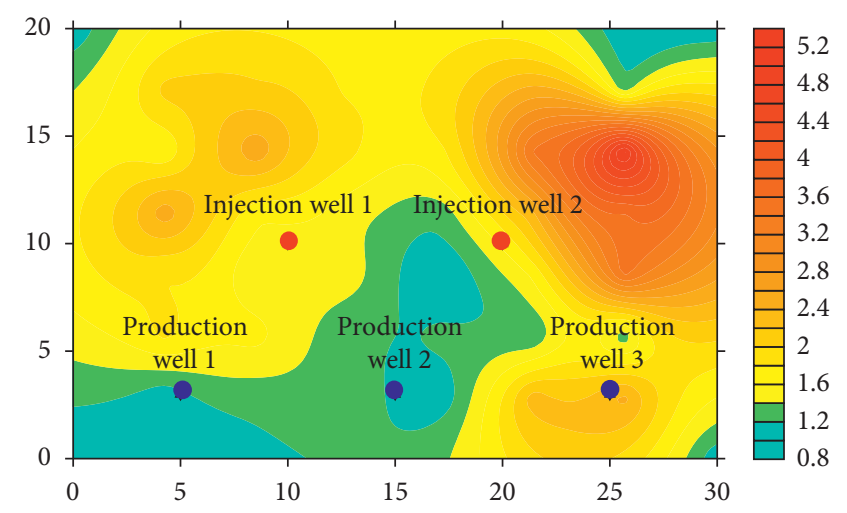

FIgURE 12: Field diagram of the dilution multiple after the chemical agent injection of $0.6 \mathrm{PV}$ with strong edge water. 


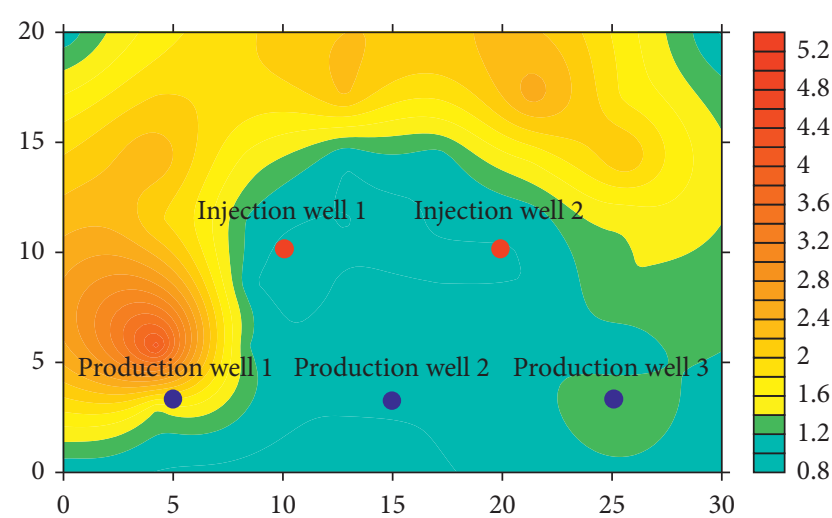

FIGURE 13: Field diagram of the dilution multiple after the chemical agent injection of $0.6 \mathrm{PV}$ with weak edge water.

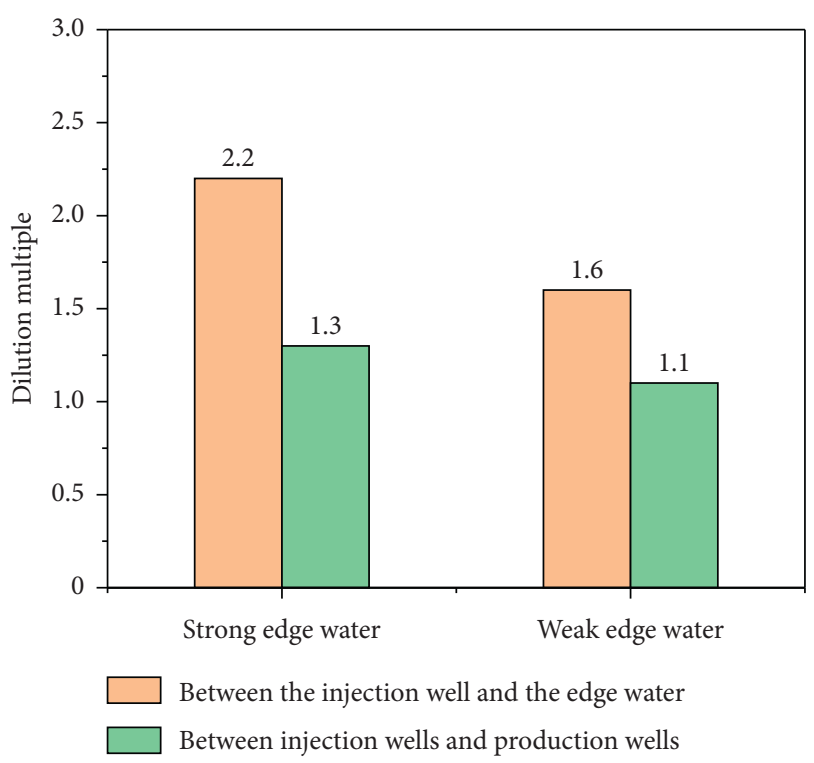

FIGURE 14: Dilution multiple of different regions under the strong and weak edge water conditions.

dilution multiple between the injection well and edge water is greater than that between the injection wells and production wells.

The dilution multiple and development effect of the polymer/surfactant binary flooding under different volumes of water invasion and different edge water energy conditions is compared (Figures 15 and 16). The invasion multiple of edge water considerably affects the dilution degree of the polymer. With the increase in the edge water invasion, the dilution multiple of the polymer gradually increases and the recovery degree for chemical flooding slowly increases. With the increase in the water invasion volume from $0.05 \mathrm{PV}$ to $0.4 \mathrm{PV}$, the polymer dilution multiple increases from 1.08 to 1.72 in the strong edge water reservoir, and the polymer dilution multiple increases from 1.05 to 1.36 in the weak edge water reservoir. The dilution degree of strong edge water is more obvious. The dilution of the edge water to the polymer leads to the decrease in the effective polymer concentration. The oil recovery loss rates for the binary

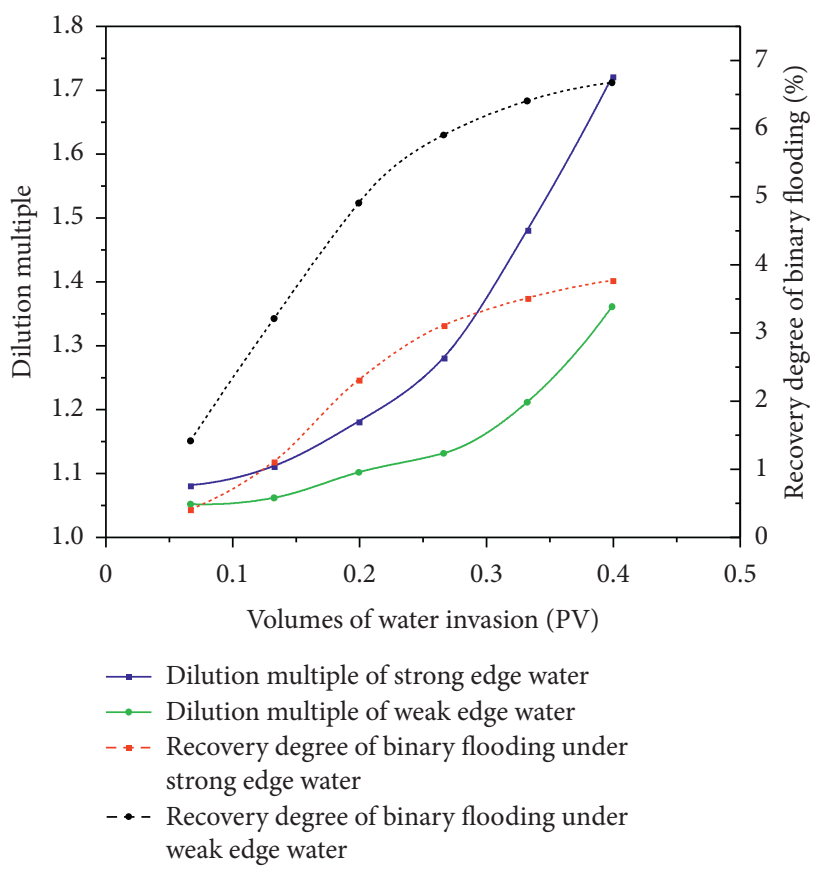

FIGURE 15: Dilution multiple under different volumes of water invasion and different edge water conditions.

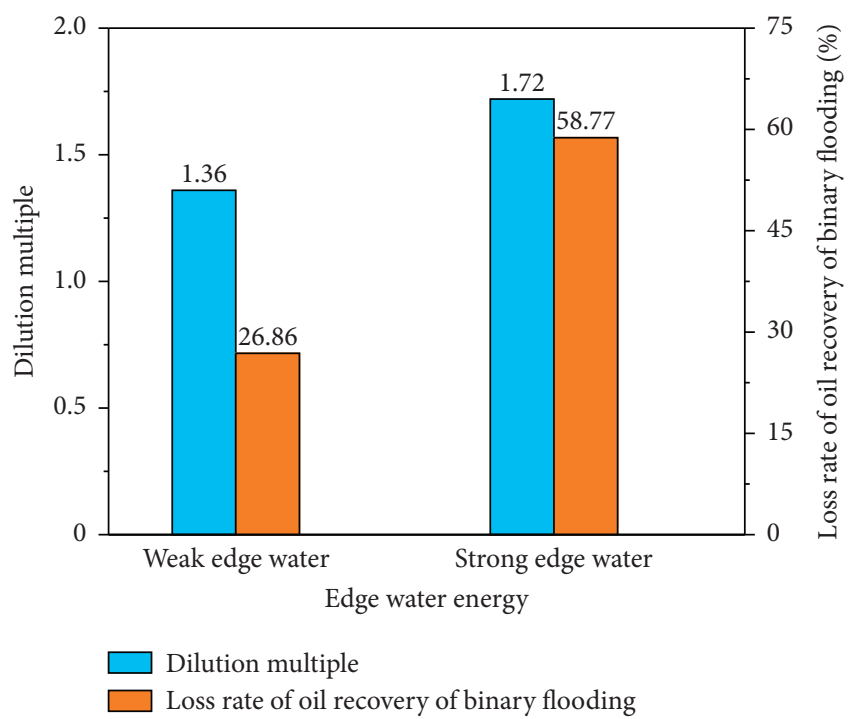

Figure 16: Effect of the edge water energy on the development effect of polymer/surfactant binary flooding.

flooding in the strong edge and weak edge water reservoirs are $58.77 \%$ and $26.86 \%$, respectively. The stronger the edge water energy, the higher the recovery loss rate for the binary flooding.

\section{Practical Guidance}

The dilution multiple reflects the dilution degree of the edge water to the chemical agent. In a majority of the reservoir areas, the chemical agent concentration is diluted by edge water, especially in the region between the injection well and edge water. The improvement of the well pattern of chemical 
Journal of Chemistry

flooding near the water/oil contact and the maintenance of a reasonable injection-production ratio and injection rate are effective methods to control the invasion of edge water and improve chemical flooding EOR.

By taking the Ng8 reservoir of the Gao104-5 fault block in the North Gaoqian area of the Jidong Oilfield as an example, it is seen that the reservoir is a typical layered structural reservoir with edge water. After several years of development, the recovery degree and composite water cut are $28.3 \%$ and $96.0 \%$, respectively. From the quantitative evaluation of the remaining oil, the residual remaining oil accounts for $66 \%$, and the retained remaining oil accounts for $34 \%$, which is mainly enriched in the top region among wells and the bypass areas along the water flooded path. The EOR technology should be adopted to improve the displacement efficiency. According to different occurrence states of the remaining oil, the differential design and combination of various displacement methods are carried out: binary flooding is implemented at the waist to improve the sweep efficiency and displacement efficiency; profile control is applied at the edge of the reservoir to plug the high capacity channel and adjust the invasion direction and invasion rate of edge water; and $\mathrm{CO}_{2}$ huff and puff is carried out in the area beyond the well pattern control. Currently, the program is being implemented, and oil recovery is predicted to be improved by $10.22 \%$.

\section{Conclusion}

(1) Experimental results revealed that the recovery degree for binary flooding without edge water is the highest, and the one with strong edge water is the lowest. The reduction of the watercut during binary flooding without the edge water is the highest, while there is marginal difference between the weak edge water and strong edge water. The stronger the edge water energy, the worse the effect of binary flooding.

(2) The concentration and distribution range of the chemical agent under the no edge water condition is clearly greater than that under the edge water condition, indicating that the chemical agent concentration can be "diluted" by edge water. The dilution degree is different in different areas, and the dilution is mainly located in the area between the injection wells and edge water.

(3) With the increase in the invasion volume of edge water, the dilution ratio of the chemical agent gradually increases. The dilution of edge water to the chemical agent leads to the decrease in the effective chemical concentration. The stronger the edge water energy, the higher the dilution multiple, and the greater the recovery loss rate by binary flooding.

\section{Data Availability}

The data used to support the findings of this study are included within the article.

\section{Conflicts of Interest}

The authors declare that they have no conflicts of interest.

\section{Acknowledgments}

This work was supported by the PetroChina Jidong Oilfield Company for research on special engineering of EOR (Project no. KF2018A03-01).

\section{References}

[1] B. Deng and W. Liu, "Water control of horizontal wells using foam-gel: lessons learnt in a heavy oil reservoir with strong waterdrive," in Proceedings of the 2017 SPE/IATMI Asia Pacific Oil \& Gas Conference and Exhibition, Jakarta, Indonesia, October 2017.

[2] J. Siemek and J. Stopa, "A simplified semi-analytical model for water-coning control in oil wells with dual completions system," Journal of Energy Resources Technology, vol. 124, no. 4, pp. 246-252, 2002.

[3] E. M. Perez, F. Rodriguez De La Garza, and F. SamaniegoVerduzco, "Water coning in naturally fractured carbonate heavy oil reservoir-a simulation study," in Proceedings of the 2012 SPE Latin America and Caribbean Petroleum Engineering Conference, Mexico City, Mexico, April 2012.

[4] X. Tu, D. L. Peng, and Z. Chen, "Research and field application of water coning control with production balanced method in bottom-water reservoir," in Proceedings of the 2007 SPE Middle East Oil and Gas Show and Conference, Manama, Bahrain, March 2007.

[5] E. Shirif, "Mobility control by polymers under bottom-water conditions, experimental approach," in Proceedings of the 2000 SPE Asia Pacific Oil and Gas Conference and Exhibition, Brisbane, Australia, October 2000.

[6] Q. Sun, Z. Li, S. Li, L. Jiang, J. Wang, and P. Wang, "Utilization of surfactant-stabilized foam for enhanced oil recovery by adding nanoparticles," Energy \& Fuels, vol. 28, no. 4, pp. 2384-2394, 2014.

[7] S. Bagci, "Seven-spot steam injection experiments in heavy oil reservoirs having a bottom water zone," Energy \& Fuels, vol. 19, no. 3, pp. 1037-1046, 2005.

[8] Z. Li, Z. Xu, B. Li et al., "Advances in research and application of foam flooding technology," Journal of China University of Petroleum (Edition of Natural Science), vol. 43, no. 5, pp. 118-127, 2019.

[9] B. Bai, J. Zhou, and M. Yin, "A comprehensive review of polyacrylamide polymer gels for conformance control," $\mathrm{Pe}$ troleum Exploration and Development, vol. 42, no. 4, pp. 525-532, 2015.

[10] Z. Li, C. Lin, Q. Shi et al., "Types of edge-water fault block reservoirs and features of residual oil in the Gaoqiannan area," Journal of Southwest Petroleum University: Science \& Technology Edition, vol. 34, no. 1, pp. 115-120, 2012.

[11] L. C. Li, S. L. Yang, and H. Chen, "Water and sand control technology successfully applied in Jidong oilfield: a case study," Energy Sources, Part A: Recovery, Utilization, and Environmental Effects, vol. 35, no. 24, pp. 2294-2301, 2013.

[12] H. Li, D. Liu, J. Cui et al., "Remaining oil distribution regularity study of complex small fault block reservoir in extrahigh water-cut period in south Gaoqian area," Petroleum Geology and Engineering, vol. 28, no. 4, pp. 74-156, 2014. 
[13] G. Zhang, "Analysis on IOR mechanism of artificial edge water flooding in complex fault-block reservoir," Fault-Block Oil \& Gas Field, vol. 21, no. 4, pp. 476-479, 2014.

[14] K. Xiao, H.-q. Jiang, and J.-j. Li, "Mechanisms of improving oil recovery efficiency by horizontal well in high water-cut stage," Journal of China University of Petroleum (Edition of Natural Science), vol. 37, no. 3, pp. 110-114, 2013.

[15] D. Han, "An approach to deep development of high water-cut oil fields to improve oil recovery ped," Petroleum Exploration and Development, vol. 22, no. 5, pp. 47-55, 1995.

[16] Z. Xu, Z. Li, A. Jing, F. Meng, F. Dang, and T. Lu, "Synthesis of magnetic graphene oxide (MGO) and auxiliary microwaves to enhance oil recovery," Energy \& Fuels, vol. 33, no. 10, pp. 9585-9595, 2019.

[17] F. Zhao, "Research progress of chemical flooding enhanced oil recovery technologies in Shengli oilfield," Petroleum \& Petrochemical Today, vol. 24, no. 10, pp. 19-22, 2016.

[18] C. Zhou, Y. Xiao, and B. Zhang, "Progress of research work on chemical flooding technology in China," China Surfactant Detergent \& Cosmetics, vol. 41, no. 2, pp. 131-135, 2011.

[19] H. Pei, G. Zhang, J. Ge et al., "Advance in enhanced ordinary heavy oil recovery by chemical flooding," Oilfield Chemistry, vol. 27, no. 3, pp. 350-356, 2010.

[20] X. Jia, G. Lei, and Z. Sun, "Review of horizontal well productivity water breakthrough in edge-aquifer oil reservoir with different drainage patterns," Special Oil \& Gas Reservoirs, vol. 25, no. 5, pp. 1-7, 2018.

[21] J. Zhao, D. Weng, P. Chen et al., "Experimental study on heterogeneous profile control physical simulation in edge water reservoir," Advances in Fine Petrochemicals, vol. 19, no. 1, pp. 32-34, 2018.

[22] L. Wang, "Control measures of the boundary water in natural water drive reservoir," Chemical Engineering Design Communications, vol. 44, no. 1, p. 176, 2018.

[23] J. Yin, C. Sun, D. Zhang et al., "The reasonable mining strength of high permeability and strong water reservoir," Petrochemical Industry Application, vol. 37, no. 1, pp. 70-73, 2018. 